\title{
Modernization of Confucianism: An Ethnographic Observation of Cultural Promoting Community
}

\author{
Xing Yu Zhu* \\ Abdul Razaque Chhachhar \\ School of Journalism and Communication \\ Tsinghua University Beijing, China 100084 \\ ${ }^{*}$ Corresponding Author
}

Doi:10.5901/mjss.2017.v8n2p137

\section{Abstract}

China is becoming one of the super powers in the world and the Chinese government is trying to promote Confucianism, the core philosophy of East Asia to the rest of the world in order to strengthen its soft power. As modernization is becoming the global process since the Cold War, the modernization of Confucianism is as well under process to fit in the new era. This article is based on a case of Confucianism promoting project to study the process and effect of cultural modernization and test how modernization helps the promotion of traditional Chinese culture. Such as, 1. The modernization will trigger voluntary and involuntary changes of the culture. 2. Cultural modernization will create a common language with other culture background people that are helpful in order to better understand Chinese traditional culture. 3. Different cultural background people are more sensitive to their own cultural elements even modernization combines various factors of traditional and modern culture or foreigner and local culture.

\section{Introduction}

China's modernization began from 160 years ago since 1840 (Li, 2001). Although the modernization happens for many years, the traditional Chinese cultural modernization is comparatively left behind. As the core philosophy in China and East Asia, Confucian influence has currently limited to a small area of learning (Yao, 1999). Study (Levenson, 1965) shows that the social, economic and politic foundation of Confucianism is greatly weakened in modern society and it is even descripted as 'a tradition of museum' or 'a historical monument' like Egyptian and Maya civilization.

This article studies a case of modernization of Confucianism by a project called Hello Kongzi (Hello Confucius). Regarding the modernization of trigger voluntary and involuntary changes of the culture. It is creating common language with other culture background people to help them better understand Chinese traditional culture and different cultural background people are more sensitive to their own cultural elements after modernization combines various factors of traditional and modern culture.

Confucianism is always playing a very an important role in the modern society. Its major thinking of loyalty, diligence, education and the respect of authority are believed to have played an important role in the industrialization process of East Asia (Chan 1996; Yu \& Lee 1995; Tai 1989; Berger \& Hsiao 1998; Morishima 1982). Chinese government is also seeking the opportunity to introduce Confucianism to the world in order to strengthen its soft power while culture now has become the driving source of conflict between civilizations instead of ideology (Huntington 1996). In 2006, President Hu Jintao called for increasing China's international status and influence through Chinese culture (Li, 2008; Ma, 2008). In 2010, Chinese government also called for a greater development of culture in order to increase the nation's soft power through traditional culture, cultural products and media (Zheng \& Zhang, 2012, p. 22). Chinese government is putting a great effort to promoting Chinese culture because they think that many Westerner's biases toward China are the result of misunderstanding the essence of Chinese culture (Lai, 2012a, p. 85). The traditional 
Chinese cultural promotion has currently become a part of the second largest economy's foreign politics (Liu \& Wang, 2007). Moreover, modernization has become a global process since the cold war; any failure of modernization of Confucius will directly lead to the failure of the promotion of Chinese culture.

In order to achieve modernization, Confucianism must achieve globalization first (Cai, 2005). For that purpose, Chinese Communist Party (CCP) has established over 500 Confucius Institutes $(\mathrm{Cl})$, an organization to promote Chinese language and culture around the world (Hanban News, 2015). Usually, the Confucius Institute cooperates with local universities for Chinese language teaching and culture promotion (Lahtinen, 2015). Studies show that Confucius Institutions is comparatively efficient so far (Xu, 2009). The project establishes the image of begin country internationally to erase the anxiety about China's increasing economic and military power (Paradise, 2009). $\mathrm{Cl}$ also creates a positive economic affect and helps China to increased export and outward Foreign Direct Investment (FDI) to developing countries (Lien, Oh \& Selmier, 2012).

The organization is one of the steps of seeking legitimacy elsewhere than China and standardizing the Chinese language internationally (Starr, 2009), which will be helpful for globalization and modernization of Confucianism. Although China is not the first country to use language and cultural institute as the part of the strategy to build up the national image (Rui, 2010), criticism comes from many aspects. Many people think Chinese government is using Confucius Institute to propagate its ideologies. It is also a threat to academic freedom because $\mathrm{Cl}$ is funded by the Chinese government (Schmidt, 2010, p. 648). Media usually reports Cl's story in a negative mood and largely unreports the organization's contribution to the cultural exchange and language learning as well (Lueck, Pipps \& Lin, 2014). This is currently the biggest challenge for the process of Confucianism around the globe.

Although Confucius Institute is mainly taking responsible for promoting Chinese culture and globalizing Confucianism, CCP will never put all eggs in one basket. The Chinese government also encourages entrepreneurs and non-profit organizations to promote Chinese culture oversea in any kind of form (Xinhua News Agency, Feb 24, 2016 \& March 3, 2016). Most of current studies of Confucian communication are focusing on $\mathrm{Cl}$ and how Confucius affects modern society. It makes the studies of the area simplex. This paper is focusing on a case study of promotion and modernization of traditional Chinese culture by a non-profit exhibition project called 'Hello Kongzi'. The strategy of the project is modernizing the traditional culture to make it fit the appetite of people with different culture. The organizer of the project is a private company in China. Until February 2016, the team has organized non-profit exhibition and workshop in Taiwan, Shenzhen, Pakistan, Canada and America to introduce Chinese culture. Each exhibition will contain 200 to 1000 sculptures of animation version of Confucian created by them. The author joined the team as a consultant. By participated observing and analyzing the afterward news report, the author was examined the efficiency of the privatesector-promoting Chinese cultural event and the communication and adaption of Confucianism in regions of different culture background.

This article is distributes in five sections firstly outline the research methods and theory framework. Then, introduce the idea of the project and how the team modernizes Confucianism. In the next two parts, mainly discuss the affect of the cultural modernization in Pakistan, United State and Canada. Described how the event absorbs the modern and domestic factors to attract the audiences to triggers voluntary and involuntary changes.

\section{Methods}

The research focuses on the process of the modernization of traditional Chinese culture and how the higher complexity of the culture attracts people who are not familiar with Confucianism. The main method of this study is ethnography. The ethnographic observation lasted for a long range of time. The author met the team of Hello Kongzi on Jan 19, 2015 at the dinner party of 'The $60^{\text {th }}$ Anniversary of the China-Pakistan Friendship Year and The Launch of Hello Kongzi Golobal Exhibition'. Then, the author worked as a consultant in their team and travel to Pakistan, Taiwan, Shenzhen, America and Canada with them intermittently until Feb 15, 2016 (See Appendix). Although the event took places in five regions, this article will mainly focus on analyzing the collective data of Pakistan. America and Canada because the article is modernization and communication with other culture, people from Taiwan and Shenzhen are already familiar with traditional Chinese culture.

By staying with the team for a long time and repeatedly joining their meetings, activities and exhibition, the author almost participates in all processes of organizing the event and knows the exhibition progress in detail. However, authors also recorded almost every steps of the breed of Hello Kongzi and witness the whole process of the modernization of Confucianism. While the drawing on interactionism (Goffman, 1963, 2010), I spent a lot of time to take notes of the people's detail including verbal exchange between audiences, face expression, body languages, gestures and participation level in the event. Other than observation, the author did an in-depth interview with the CEO of the company 
and analyzed the news report about 'Hello, Kongzi'. Moreover, author meets many people in Taiwan, Pakistan, America and Mainland China. This gives an opportunity to have a discussion not only with the project team, but also with the local officials, company, members of associations, artist who join the project as partners. Mainly, discuss the issue of promoting and modernization of Confucianism with these professional event organizers, public relationship company stuffs, administrators or new media directors. They will provide different angles of same questions.

As the author had spent a lot of time with the team and deeply participates into the organization of the event, the collective data is comprehensive and minute. This article will mainly use observation notes, assisted by interview of the key people of the project team and text analyze of the news of the event, to answer the questions of how modernization of Confucianism helps to promote the traditional Chinese culture, what effect does modernization do on traditional Chinese culture and how modernization increases the complexity of Confucianism.

\section{Theory Framework}

This article is using cultural modernization theory to examine the cultural revolution of Confucianism. Modernization theory is considered as a natural and unavoidable development that all culture must go through. It is now broadly studied in the aspects of economy, politic, culture, environment, science, ecology and tourism (Li, 2001, Chen, 2014, Blaney \& Inayatullah, 2002, Brewis \& McGarvey 2000). Cultural modernization can be involuntary and voluntary, such as the influence of technology and more complex social organization imposed by the dominant culture or changes in role expectations and material culture desired by the members (Divale \& Seda, 2001). The balance between the tradition and the modern is extremely important because radical process of modernization can stimulate social problems by contradicting the traditions (Ince, Yarali \& Ozsel, 2009). Gerhards and Hackenbroch's (2000) study shows that cultural modernization involves secularization, the change of family tradition, individualization and globalization and people need to increasingly provide their own meaning by drawing from foreign culture.

Cultural modernization will result a culture with higher degree of complexity because the traditional culture will borrow facts from the new culture (Divale \& Seda, 2001), but if we take a look at the traditional Chinese culture now, we cannot see much combination between traditional and modern culture. The Chinese culture is still inundating with the ancient tradition. Confucianism was once seem as superior to the indigenous culture in Ming and Qing dynasties, but it was repressed by stronger Japanese culture during WWII and currently challenged by the modern Western culture (Chen, 2009). Although Confucianism is the crystal of the wisdom of Chinese ancestors, they are usually hard to be understood by people who are not familiar with Confucianism and blocking the ways of the cultural communication between East and West (Tian, 2009). Its light is fading away nowadays. The huge gap between Eastern and Western ideology is the key issue of modernization of Confucianism. So, one of the purposes of Confucianism modernization is to be more understandable by different cultural background.

\section{Hello Kongzi and Hello Kitty}

The idea of Hello Kongzi comes from the most successful Japanese cultural symbols, Hello Kitty. How does the idea of Hello Kongzi born is the very first step of the modernization of Confucianism in the project because it is standing on the shoulder of success of the modern cultural products. Hello Kitty is a staple of the Japanese culture ever since (Takagi, 2008). It is a cute cat that is always wearing pink. It attracts young generation, especially female by its cuteness. Although the cute culture was not found by business and it is the result of Japanese youth culture (Kinsella, 1995), the cat has proven its economic and cultural power to the world. In 1999, a promotional campaign raise by McDonald's sold 250,000 Hello Kitty dolls with the special meal packages in just two hours. (Cheng, 1999) The largest telephone company in Taiwan, Chunghwa Telecom Company, sold 50,000 'Hello Kitty Phone Card' in just five minutes. (Lee, 1999) Even an airline company used it to feature its jet to successfully attract customers (Wang, 2015). Beside economic effect, scholars focus on the cultural influence of the animation too. As the Japanese commodities sweep up the local consumers, Japanisation is becoming one of the most important issues of Taiwan. (Ko, 2003) Japanese animation drama and products also have created an identical crisis around the world. 'Hello Kitty represents a symbol of youthful innocence and enables women to retreat into a childlike state of mind.' (Kovarovic, 2011) According to Joseph Nye's (2006) thesis, Japan is spreading out its influence by the soft power 'cuteness'.

Hello Kitty has created a one-way ticket to the 'cool table' for itself and is deeply influencing younger generation (King, 2015). Study shows that younger people have more positive attitude to animation than older people. (Hernandez \& Hirai, 2015) Japanese animation has created its own fan group and become a significant social and cultural wave that caught Taiwan, Korea, Mainland China and even America. (Wilson \& Toku, 2004, p. 94-103) In the postmodern time, pop 
culture, including animation, has somehow overcome traditional culture. There are thousands of products using Hello Kitty as a successful promotional strategy, but traditional Chinese culture does not have such kind of economic and ideological influence. It is because traditional Chinese culture is not cool while the pursuit of being cool has become the major element of global consumer culture (Belk et al., 2008).

By promoting Confucianism in the postmodern world, Hello Kongzi wants to avoid a direct competition between traditional culture and modern culture. After several meeting, the team decided the best way is fusing both traditional culture and modern culture. After studying several cultural products around the world, including Disney, Hello Kitty and Marvel etc, the team decided to use Hello Kitty's strategy to create a cute Chinese cultural symbol, Hello Kongzi. The reason of choosing Hello Kitty strategy is because it apparently will work at least in Asian. The modern factors the organizor choose for Hello Kongzi is cute and fun while keeping some tradition factors of Confucius such as older in age, polite and education. The sculptures look cute but with beard and their motions are the gestures of politeness. There is a writing brush that represents traditional Chinese education on the head of the sculptures. This is an effective combination of both tradition and modernity, which will keep the two sides balance and be understandable by both Easterners and Westerners.

\begin{abstract}
While the exhibiting in Taiwan, most of the audiences the team met can recognize it is Confucius even it looks very different and cuter than traditional image. Chinese parents in the exhibition will tell their children something about who Confucius are, what did he do and his doctrines during the visiting. While we are exhibiting in USA, most of the audiences do not know who it is at the first place, but they are attracted by cute sculptures and willing to spend more time in the exhibition. Discussions among American people are usually focusing on modern factors such as the fashion, music or art. (Observation note, Jan 2, 2015 and Jan 30, 2016)
\end{abstract}

People from Taiwan and Americans are sensitive to different factors depending on their own cultural background. Asians are also attracted by modern elements, but Asians will recognize the identity of the sculptures immediately and have more discussion about the tradition than American. Educational concept of Confucius is still occupying modern Chinese people's thinking even the project is showing a very different version and trying to intimate Hello Kitty. Otherwise, without the Confucius background, Americans are more sensitive than elements such as fashion, cute or modernity. The audiences will decode different information from the modernized Confucius when Confucius's image is changed. Hello Kongzi project shows that the modernization is increasing Confucius complexity by effectively combing both Chinese traditional culture and modern culture. Also the project currently is not used for business like Hello Kitty, but it has go beyond the narrow usage of Confucianism. Hello Kongzi is not only an educational project like Confucianism mostly did in the history, but also it is trying to represent fashion or entertainment.

\title{
5. Mutual Triggers of Voluntary and Involuntary Changes
}

There is a lot of critic about the inflexible Confucian education. This makes Confucius and its doctrines always give people a dry and boring impression. Textual evidences show that Confucius Heritage Culture $(\mathrm{CHC})$ countries share a very closed education system advocating rote-memorization, transmission of knowledge via teacher-centredness, low interactive process and top-down method. (Han \& Scull, 2010) 'In contrast to Western education in which students are encouraged to engage in debate, Confucius education tends to emphasize rote learning and memorization.' (Aoki, 2008) Some scholars even regard traditional Chinese culture as authoritarianism (Li, 2001). Despite few studies argued that Confucius actually rejects rote-memorization (Tan, 2015), the negative opinion is deeply rooted in people's mind. So, the company found that the philosophies of Confucianism are educationally helpful, but the stereotype of rigid image is preventing foreigners from adapting Confucian.

'One of the biggest issues of promoting Confucianism is how to tell the stories in a modern way. We want to create a relax image for Confucius. We are trying to combine Pop culture and Confucianism to create a new brand for Confucianism and change people's expectation from Confucianism.' (Interview with Pandora Pan, Feb 21, 2016)

'What mattered was that she (Hello Kitty) was cool, and by owning even a small Hello Kitty branded item, you too could become cool.' (King, 2015) The easiest way for Hello Kongzi to attract people is to use the same formula of Hello Kitty. During the creation of Hello Kongzi, the company is trying to start from cute dolls as Hello Kitty. The team firstly designed and produced some cute sculptures of Confucius with different gestures to create a new image for Confucius. The sculptures are mainly used to attract people's attention. The organizor also made some billboards of the doctrines of Confucianism and put them among the sculptures. People will read the billboards during taking pictures with the cute 
sculptures. Further more, the team modernized Confucius by adding high technology and pop culture. A pop star was hired from Taiwan to create a pop song for Hello Kongzi and used facial capture, animation creation technology to interact with their audiences. This is a different way of communication than lecturing in classroom. The exhibition always take places at the landmarks of different cities such as Times Square in New York, Pakistan Monument in Islamabad, Capital Hill in Ottawa because there are more visitors in these location. After the reshaping and modernization of Confucius, totally different Confucius with higher degree of complexity is reproduced. Hello Kongzi is not only containing the doctrines and philosophies of Confucianism, but it absorbs more factors that it does not have before, such as modern technology, music and animation. People's now have a more complex expectation from Hello Kongzi as well. The society are not only looking for knowledge now, but also fun, entertainment and art from the rebirthed culture.

The cute strategy is well working. All people the team met (include kids and adults) show a great interest in the cute sculptures before having a clue of who it is. Almost everyone took a selfie or picture with the sculptures and share them on Internet and successfully spread out the event and Confucius. There is over 100 million forwarding of the Taiwan exhibition on Weibo (the Chinese Twitter) and 2 million clicks on Facebook. (Observation note, Jan 30, 2016)

By adding the cute factors, pop culture and high technology into Confucius, it triggers the chain effect of modernization and result a mutual trigger of voluntary and involuntary changes of Confucianism. The team firstly embeds modern elements into the traditional culture in order to voluntarily change the expectation of the audiences. People are looking for elements such as fun, entertainment or art from Confucius instead of just knowledge and doctrines in the old day. The voluntary changes then trigger the involuntary modernization. People put their pictures on social media that created a big impact to the event.. By letting more people know about the event on Internet, technology enlarged the influence of Confucianism and further more broke down the old-fashioned image of Confucianism and reversed the tradition of studying Confucian.

In observation, combining modern factors is successful in terms of promoting Confucius and Chinese culture. Not only the event, the audiences themselves are promoting the Hello Kongzi project by sharing the pictures on the social media. The promotion event attracts people, especially youths, by the cute sculptures first instead of giving them lecture directly. After people pay more attention to Hello Kongzi, the participants started asking questions like 'who is this old man' or 'what does he do in China?' The cute image lighted up people's curiosity and changed their expectation to increase their interest of studying Chinese culture. Higher interest will help people to accept the cross-nation culture when the team introduces the stories and philosophies to the audiences.

'We do not want to give lesson in the first place because it will bore people and make them turn away.' (Interview with Yizhou, Ye on Feb 20, 2016)

\section{Creating Comment Language During Modernization}

The exhibition event is always looking for localizing the Confucian when entering a new country. Hello Kongzi holds a 6days exhibition in Pakistan. Although Pakistan is the closest ally of China, the two countries have very different cultural and religion background. The relationship of two countries are often descripted as 'higher than mountain, deeper than ocean, harder than steel and sweeter than mountain' by the officials, but the people of two countries rarely know each other. Most of people met in Pakistan, especially with lower education level, know nothing about Confucian. So the biggest challenge of the cultural exchange between China and Pakistan is how to explain the cultural and philosophies to each other while the cultural background is totally different.

'Our team spent most of our time to study Muslim and plan our event to avoid any conflict with local beliefs. Because we know any offence of their religion might lead to immediate failure of the event.' Said by Yizhou Ye, the CEO of the company. 'It want to find some common factors between Confucian and Muslim because It believe that the local people to understand Confucian better.' (Interview, Feb 20, 2016)

The processes of modernization will change the language and create pidgin languages (Homer, 1906; U.S. Navy Department, 1944). The promotion team is using multimedia and cultural localization in order to create a new language that can be understood by both sides. The event firstly took place at Pakistan Monument, F6 Market, Lakeview Park, Pakistan Monument Museum, Cricket Ground and Taxila and displayed over 200 Hello Kongzi sculptures from Sep 1, 2015 to Sep 7, 2015. These places has higher amount of visitors and can successfully gain people's attention. Secondly, the team changed the name of 'Hello Kongzi' into 'Salaam Confucian' in order to increase the appetency. Thirdly, the 
team recreated all the original art work into a Salaam pattern, including a new sculpture of Pakistan version which wearing green (the national color of Pakistan) clothes and hijab. The team also hired a local artist to create illustrations for Confucius doctrines of 'benevolence', 'righteousness', 'manners', 'wisdom' and 'credit' (Figure 2) and shot a documentary video in Pakistan in order to let local people understand Confucius better. These illustrations are showing the doctrines of Confucius by the local art philosophies. All the illustrations and videos were uploaded on the official account of Hello Kongzi of Facebook and Twitter.

'This (The illustrations) is helpful for me to understand the Chinese philosophies because the artist is using their own language and art to explain the doctrines. He is sending the message with Pakistani art and thinking.' (Interview with the Pakistani audiences, Sep 2, 2015)

Beside multimedia and art, the team of the exhibition localized Chinese traditional culture with the doctrines of Pakistani philosopher, Muhammad Iqbal, to explain Confucian. Muhammad lqbal has the same reputation in Pakistan as Confucian does in China. The exhibition team found Muhammad Iqbal's philosophies of peace and harmony is very helpful for promoting Confucian in Pakistan. The organizor always told Pakistani audiences that Confucius is 'Chinese Muhammad Iqbal' who advocates peace and harmony and how should a person behave. This would help Pakistanis to get the straight idea of who Confucian is and what does he mean to China.

It shows that during the modernization, the team is trying to create a new language for Pakistanis. The new language can be oral and non-oral like comment philosophies, pictures, art or clothing etc.

The biggest advantage of multimedia and art promotion is to erase the language obstacle. People are learning Confucian by watching video to get the ideas from the music, pictures and paintings instead of language. 'We are not sure if we can send the message correctly and accurately to the audiences by translating the doctrines into Urdu. So we use video, painting instead of language.' (Interview with Pandora Pan, Feb 21, 2016)

Deserve to be mentioned, the good relationship of China and Pakistan also plays a part of common language helping promote Chinese culture. In the last day of the event in Pakistan, the team met with the President of Pakistan, Mamnoon Hussain, to discusses further cultural exchange with the country. The President and other officials showed a great support of the event. The President appreciated the exhibition event and said these would increase the contacts and relations between the two countries and the people of China and Pakistan. (The News, September 8, 2015)

Pakistan-China Institute Chairman Senator Mushahid Hussain Sayed says that the exchange of the culture between Pakistan and China will helps to unite of the two Countries. This kind of Pakistan and China cultural exchange event should be called Pak-China cultural corridor and its main purpose is teaching and understanding of Confucianism. (Pakistan Times, September 7, 2015)

\section{Modernization Helps Promoting Confucianism and Chinese Culture}

Since China and America has become two of the most influential countries in the world (Zhao, Zhou \& Huang, 2008), the communication between Confucius and western countries is crucial. So, the organization holds a 15-days-exhibtion in Canada and America. North Americans know more about China and Confucius than Pakistanis. The Chinese government has made a lot of effort to maintain and strengthen its relationship with US since the two countries established diplomatic relations (Wang \& Shoemaker, 2011). The Chinese language learners and cultural exchanges have facilitated the communication with China. (Lahtinen, 2015) Although this will make the promotion of Chinese culture easier, there are still some misunderstanding and stereotype between the two super powers. (Lueck, Pipps \& Lin, 2014) The growing power of China has also breed the China threat theory, which claims that China poses a threat to the western countries (Huntington, 1993; Scott, 2007).

The strategies of promoting Confucian in North America are both localization and strengthen the participation of audiences. The team set up an exhibition of the Hello Kongzi sculptures and made both Canadian style and American style Hello Kongzi as in Pakistan. The team made a hockey and Uncle Sam version of Hello Kongzi that can represent the two countries' spirit to localize the event. Just like in Pakistan, the special version of the Hello Kongzi sculptures are very popular among people as local society finds it familiar to their own experience. Also a local band was hired to do the pop music performance in order to enrich the exhibition. However, the project manager thought this would not be enough to impress the visitors as many of them already have a brief idea about China. Experience occurs when companies intentionally engage consumers in a way that creates a memorable experience. (Pine \& Gilmore, 1998) So, the team 
wanted to create a memorable experience for the audiences through participation. They built a workshop of Hello Kongzi at the Highland Center in Los Angeles that includes several games of Chinese culture. The theme of the workshop is Chinese New Year and the house is decorated with red and all New Year elements. Visitors can learn writing the doctrines of Confucianism with Chinese brushes and color the Confucius sculptures. The event was creating a physical experience of Chinese culture for the audiences. This strategy turned out successfully attracting people to stay longer at the exhibition than in Pakistan and gave a basic idea of what Chinese culture is. All kids and adults are showing a great interest in both watching the band show and participating in the games. In the end of the event, the team made a video (Official Website of Hello Kongzi) with the interview of the participants. This video shows how participants actually learn and getting more interest about Chinese culture from the event:

- 'The audiences enjoy the art and it is very beautiful. Look like the red everywhere. Parade and architecture is my favor.'

- 'The Chinese culture is the meditation and the discipline. It is about being who you are and knowing who you are from within.'

- 'Moreover, to go to the Chinese New Year.' 'Yeah, and celebrating it right now.'

- 'This is like the first time that many audiences are doing something about Chinese art.'

From the interview of the audiences, it can see art and other non-oral common languages are become an important connection between people and Confucianism. They get some idea of Confucianism and Chinese culture (such as meditation, discipline, Chinese New Year) through art. Modernization will raise their interest and letting them know about Confucianism and also feel the Chinese art.

\section{Conclusion}

China is rising as a super power nowadays and the nation plays a more important role and has a great influence economically and culturally to the rest of the world. As the core thinking of Chinese society, Confucianism becomes the primary philosophy that China communicates with the world. How to tell the stories of Confucius is crucial to Chinese soft power. This makes the Hello Kongzi case important because it represents the modernization of Confucianism, the core philosophy of China. Despite the fact that Confucianism and Chinese education system always give people an oldfashioned impression, Hello Kongzi successfully use the strategy of Hello Kitty to promote Confucianism in a fun way. From this case, there are few factors are very helpful for promoting the culture in other countries through modernization:

Mutually trigger of voluntary and involuntary changes: The case shows that successfully combining the traditional and modern culture is helpful for promoting Chinese culture oversea. By adding elements like cute, music, art, high technology, Hello Kongzi changes the expectation of people from Confucius. This voluntary change then trigger the involuntary change of the influence of social media by the pictures audience shared. Then, picture sharing is letting more people knowing the event and further more change more people's expectation from Confucius.

Modernization is creating Common Language: Chinese ancient philosophies are always hard for foreigners to understand, but the study shows that modernization is creating a common language for different culture background that is helping people to understand about the ancient doctrines. These common languages do not have to be oral language. It can appear in various forms like art, picture or celebrity. The By making the doctrines fun, it is easier for people to learn and accept the core value of Chinese culture. The combination of pop music and traditional culture increases the enjoyment of the audiences to a strange culture. Although the doctrines of Confucianism is acknowledged as wisdom, but the stereotype of boring and inflexible of the traditional culture is preventing people to learn the doctrines. The project team put a great effort in removing this obstacle. The modernization of Confucianism helps breaking the stereotype.

Participation: When Hello Kongzi team built up a workshop of Chinese culture, audience's participation effectively raises their interest in Chinese culture and learning. The games in the workshop gave the audiences a physical experience and memorization that are better spreading out the culture. The team also used different format of promotion in different regions. Instead of just lecturing and teaching, the exhibition team has done a lot of localization and innovation about the Chinese culture to make it more acceptable to foreigners.

Different reading: Modernization will combine both traditional and modern factors because losing balance of the two will lead to a series of problem. People with different cultural background will be sensitive to the elements that closely related to its own background. People from Confucius country (China, Japanese, Korea) will be more sensitive to the traditional Confucius cultural such as education and knowledge. Westerners, without Confucius background, then are more sensitive to modern elements such as fashion, pop culture and cuteness.

The observation of the long-range time of the event, modernization is very helpful for promoting Chinese culture 
and Confucianism to the rest of the world. By combing the traditional and modern factors, Confucianism is showing itself with a new face while keeping the main ideas and philosophies. On one hand, modern factors such as cute, pop culture, fashion and art make Confucianism become more attractive and understandable to people who do not have Confucian background. On the other hand, traditional factors are sending the message of philosophies to the audiences. The efficient combination of two is greatly erase the obstacles and filling the cultural gap of different culture.

Appendix: Agenda of Hello Kongzi Exhibition:

\begin{tabular}{|c|c|c|}
\hline Times & Event & Location \\
\hline Jan 19, 2015 & $\begin{array}{l}\text {-The } 60^{\text {th }} \text { Anniversary of the China-Pakistan Friendship Year and The } \\
\text { Launch of 'Hello, Kongzi' Global Exhibition Dinner Party }\end{array}$ & Diaoyutai State Guest House, Beijing \\
\hline $\begin{array}{l}\text { Dec 23, 2014-Jan 4, } \\
2015\end{array}$ & Exhibition at Confucian Temple & Taiwan \\
\hline $\begin{array}{l}\text { Dec 27, 2014- Dec 28, } \\
2014\end{array}$ & Exhibition at The Place Museum of Taiwan & Taiwan \\
\hline $\begin{array}{l}\text { Dec 30, 2014- Jan 4, } \\
2015\end{array}$ & Exhibition at Kaitakelan Boulevard & Taiwan \\
\hline Jan 2, 2015- Jan 4, 2015 & Exhibition at Taiwan Government & Taiwan \\
\hline $\begin{array}{l}\text { Jan 31, 2015- Feb 28, } \\
2015\end{array}$ & Exhibition at Fo Kwang Mountain & Taiwan \\
\hline Sep 2, 2015 & $\begin{array}{l}\text {-First Day of Exhibition (200 Sculptures) } \\
\text {-Shooting Hello Kongzi Video }\end{array}$ & $\begin{array}{l}\text {-Pakistan Monument, Islamabad } \\
\text {-Lakeview Park, Islamabad }\end{array}$ \\
\hline Sep 3, 2015 & $\begin{array}{l}\text {-Second Day of Exhibition (200 Sculptures) } \\
\text {-Shooting Hello Kongzi Video }\end{array}$ & $\begin{array}{l}\text {-Pakistan Monument, Islamabad } \\
\text {-Pakistan Monument Museum, } \\
\text { Islamabad }\end{array}$ \\
\hline Sep 4, 2015 & $\begin{array}{l}\text {-Third Day of Exhibition ( } 20 \text { Sculptures) } \\
\text {-Shooting Hello Kongzi Video }\end{array}$ & -Cricket Ground, Islamabad \\
\hline Sep 5, 2015 & $\begin{array}{l}\text {-Forth Day of Exhibition (20 Sculptures) } \\
\text {-Shooting Hello Kongzi Video }\end{array}$ & -F6 Market, Islamabad \\
\hline Sep 6, 2015 & $\begin{array}{l}\text {-Fifth Day of Exhibition (10 Sculptures) } \\
\text {-Shooting Hello Kongzi Video }\end{array}$ & -Taxila, Pakistan \\
\hline Sep 7,2015 & $\begin{array}{l}\text {-Sixth Day of Exhibtion (200 Sculptures) } \\
\text {-Shooting Hello Kongzi Video } \\
\text {-Meeting with the President of Pakistan }\end{array}$ & $\begin{array}{l}\text {-Pakistan-China Friendship Centre, } \\
\text { Islamabad } \\
\text {-Pakistan Presidential Palace, } \\
\text { Islamabad }\end{array}$ \\
\hline Jan 28, 2016 & -Arrived Canada and started the North America Exhibition & -Ottawa, Canada \\
\hline $\operatorname{Jan} 29,2016$ & Meeting with the Cultural Counselor of Chinese Embassy & -Ottawa, Canada \\
\hline Jan 30, 2016 & $\begin{array}{l}\text {-Hello Kongzi Exhibition } \\
\text {-Shooting Video }\end{array}$ & -Capital Hill, Ottawa, Canada \\
\hline Feb 1 to Feb 12, 2016 & $\begin{array}{l}\text {-Hello Kongzi Exhibition } \\
\text {-Shooting Video }\end{array}$ & $\begin{array}{l}\text {-Highland Center, Los Angeles, } \\
\text { America }\end{array}$ \\
\hline Feb 20, 2016 & Interview with the Yizhou Ye (CEO of the company of Hello Kongzi) & \\
\hline Feb 21, 2016 & Interview with Pandora Pan (the Project Manager of Hello Kongzi) & \\
\hline
\end{tabular}

\section{Reference}

Aoki, K. (2008). Confucius vs. Socrates: The impact of educational traditions of East and West in a global age. The International Journal of Learning, 14(11), 35-40.

Belk, R.W., Tian, K. and Paavola, H. (2008). Consuming cool: Behind the unemotional mask. Research in Consumer Behavior, (12): 183-208

Berger, P., \& Hsiao, H. M. (1988). In search of an East Asian Development Model, (New Brunswick: Transaction Books)

Blaney, D. L. \& Inayatullah, N. (2002). Neo-Modernization? IR and the Inner Life of Modernization Theory. European Journal of International Relations, 8(1), 103-137

Brewis, A. A. \& McGarvey, S. T. (2000) Body image, body size, and Samoan ecological and individual modernization. Ecology of Food and Nutrition, 39(2), 105-120

Cai, D., (2005). Ru Xue Zai Gang Ao Tai He Hai Wai De Xin Ji Yu (The new opportunity of Confucianism at Hong Kong, Macao, Taiwan and oversea), Academics in China, 257-279 
Chan, A. (1996). Confucianism and Development in East Asia. Journal of Contemporary Asia, 26(1), 28-45

Chen, C. (2009). Development of Confucianism in Taiwan. Contemporary Chinese Thought, 41(1), 10-27

Chen, L. (2014). Cultural impact of modernization and tourism on Dai villages in Xishuangbanna, China. Tourism Geographies, 16(5), $757-771$

Cheng, Nien-Chi. (1999) Uncle McDonald in Panic, Hello Kitty Sold Out, Commonwealth (Taipei), p 56.

Divale, W. \& Seda, A. (2001). Modernization as changes in cultural complexity: New cross-cultural measurement. Cross-Cultural Research, 35:2,127-153

Gerhards, J. and Hackenbroch, R. (2000). Trends and Causes of Cultural Modernization. International Sociology, 15(3), 501-531

Goffman, E. (1963). Behavior in Public Places: Notes on the Social Organization of Gatherings. New York: The Free Press.

Goffman, E. (2010). Relations in Public: Microstu- dies of the Public Order. London: Transaction.

Han, K., \& Scull, W. (2010). Confucian culture in the mainstream classroom: A case study of an Asian American student. The International Journal of Learning, 17, 601-616.

Hanban News, The 10 th Confucius Institute Conference to be Held in Shanghai soon, 4 September, 2015, http://english.hanban.org/article/2015-12/04/content_626193.htm

Hernandez, A. D. H. \& Hirai, T. (2015). The Reception of Japanese Animation and its Determinants in Taiwan, South Korea and China. Animation: an interdisciplinary journal, 10(2), 154-169.

Huntington, S. (1996). The clash of civilizations and the remaking of world order. New York: Simon \& Schuster.

Huntington, S.P. (1993). The clash of civilizations? Foreign Affairs, 72(3), 22-49

Ince, H.O., Yarali, A. and Özsel, D. (2009). Customary Killings in Turkey and Turkish Modernization, Middle Eastern Studies, 45(4), 537551

King, E. L. (2015). Pink Globalization: Hello Kitty's Trek Across the Pacific. The Asia Pacific Journal of Anthropology, 16(2), 194-196.

Kinsella, S. (1995). 'Cuties in Japan' in Women, media and consumption in Japan. Skov L. and Moeran B. (eds.), Honolulu, Hawaii, University of Hawaii Press.

Ko, Yu-Fen (2003). Consuming differences: 'Hello Kitty' and the identity crisis in Taiwan, Postcolonial Study, 6(2), 175-189.

Kovarovic, S. (2011). Hello Kitty: A brand made of cuteness. Journal of Culture and Retail Image, 4(1), 1-8.

Lahtinen, A. (2015). China's Soft Power: Challenges of Confucianism and Confucius Institutes. Journal of Comparative Asian Development, 14(2), 200-226,

Lai, H. (2012a). China's cultural diplomacy: Going for soft power. In H. Lai \& Y. Lu (Eds.), China's soft power and international relations (pp. 83-103). London: Routledge.

Lee, Yan-Fu, 'Hello Kitty Phone Card Sold Out in Five Minutes', United Daily (Taipei), 16 December 1999, p 6

Levenson, J. R. (1965). Confucian China and its Modern Fate, Vol. 3: The Problem of Historical Significance (London, Routledge \& Kegan Paul)

Li, M. (2008). China debates soft power. Chinese Journal of International Politics, 2, 287-308.

Li, S. (2001). China's Cultural Tradition and Modernization, Contemporary Chinese Thought, 33(2), 63-91

Lien, D., Oh, C. H. \& Selmier, T. (2012) Confucius institute effects on China's trade and FDI: Isn't it delightful when folks afar study Hanyu?, International Review of Economics and Finance, 21, 147-155

Liu, Q., \& Wang, L. (2007). Review of soft power studies. International Forum, 2007(3). Retrieved on from http://en.cnki.com.cn/Article_en/CJFDTotal-GJLT200703006.htm

Lueck, T. L., Pipps, V. S. \& Lin, Y. (2014). China's Soft Power: A New York Times Introduction of the Confucius Institute. Howard Journal of Communications, 25(3), 324-349

Ma, L. (2008). Guanyu woguo jiaqiang ruan shili jianshe de chubu sikao (Preliminary thoughts on accelerating China's soft power building). Dang de Wenxian (Literature of the Chinese Communist Party), 7, 35-38.

Morishima, M. (1982). Why Has Japan Succeeded?: Western Technology and Japanese Ethos (Cambridge: Cambridge University Press)

Nye, J.S. (2006) Transformational leadership and U.S. grand strategy. Foreign Affairs, 85(4): 139-148

Official Website of Hello Kongzi, http://www.hellokongzi.com.cn/index.php/index/exhibi/id/17.html

Pakistan Times, 'Salaam Confucius' set to promote Chinese culture in Pakistan, September 7, 2015, http://www.pakistantoday.com.pk/2015/09/07/news/salaam-confucius-set-to-promote-chinese-culture-in-pakistan/

Paradise, James F. (2009). China and International Harmony: The Role of Confucius Institutes in Bolstering Beijing's Soft Power. Asian Survey, 49(4), 647-669

Pine, B. J. and Gilmore, J. H. (1998). Welcome to the experience economy. Harvard Business Review, 76(4), 97-105.

Rui, Y. (2010). Soft power and higher education: An examination of China's Confucius Institutes. Globalization, Societies and Education, $8,235-245$

Schmidt, P. (2010). At U.S. colleges, Chinese-financed centers promote worries about academic freedom. Chronicle of Higher Education, 57, A8-A10.

Scott, D. (2007). China stands up: The PRC and the international system. New York, NY: Routledge

Shakir, Naeem. (2015). Islamic Shariah and Blasphemy Laws in Pakistan, The Round Table, 104(3), 307-317

Starr, D. (2009). Chinese Language Education in Europe: the Confucius Institutes, European Journal of Education, 44(1), Part I, $65-81$

Tai, H. (1989). Confucianism and Economic Development: An Oriental Alternative? (Washington, D.C.: The Washington Institute Press) 
Takagi, J. (2008, August). 10 Questions for Yuko Yamaguchi. Retrieved from http://content.time.com/ time/magazine/article/0,9171,1834451,00.html

Tan, C. (2015). Beyond Rote-Memorisation: Confucius' Concept of Thinking, Educational Philosophy and Theory, 47(5), 428-439,

The News, Pak, China leaders committed to complete cpec projects: Mamnoon, September 8, 2015 http://www.thenews.com.pk/print/61172-pak-china-leaders-committed-to-completing-cpec-projects-mamnoon\#

Wang, S.W. (2015). The experience of flying with Hello Kitty Livery Featured Theme Jet: moderating effects of destination image, Current Issues in Tourism, 18(2), 99-109

Wang, X. and Shoemaker, P. J. (2011). What shapes Americans' opinion of China? Country characteristics, public relations and mass media, Chinese Journal of Communication, 4(1), 1-20

Wilson, B. \& Toku, M. (2004). "Boys' Love", yaoi, and art education: issues of power and pedagogy, In D. L. Smith-shank (Ed.), Semiotics and visual culture: Sights, signs, and significance. Teston, VA: National Art Education Association

Xinhua News Agency, Liu Zhou Gu Li Min Jian Zi Ben Tou Ban Wen Hua Qi Ye (Liuzhou encourages private capital to invest in cultural enterprise), 24 Feb 2016, http://big5.xinhuanet.com/gate/big5/www.gx.xinhuanet.com/wq/2016-02/24/c_1118143224.htm

Xinhua News Agency, Wen Hua Zou Chu Qu Cheng Guo Xian Zhu (The cultural going out strategy bears fruit), 1 March 2016, http://news.xinhuanet.com/politics/2016-03/01/c_128763790.htm

$\mathrm{Xu}, \mathrm{L}$. (2009). Presentation at the Joint Conference of European Institutes. Leuven, Belgium, 18 October 2009.

Yao, X. (1999) Confucianism and its Modern Values: Confucian moral, educational and spiritual heritages revisited. Journal of Beliefs \& Values, 20(1), 30-40.

Yu, T. \& Lee, J. S. (1995). Confucianism and Economic Development (Taipei: Chung Hua Institution for Economic Research)

Zhao, Y., Zhou, X. and Huang, L. (2008). Chinese Students' Knowledge and Thinking about America and China. The Social Studies, $99(1), 13-22$

Zheng, Y. and Zhang, C. (2012). "Soft power" and Chinese soft power. In H. Lai \& Y. Lu (Eds.), China's soft power and international relations (pp. 21-38). London: Routledge. 